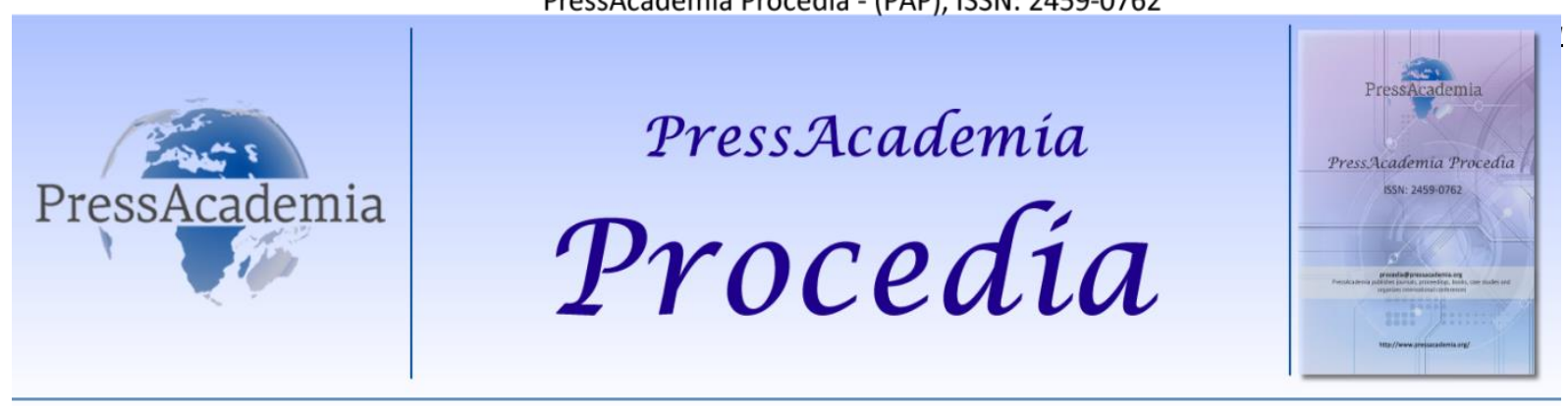

2nd World Conference on Technology, Innovation and Entrepreneurship,

May 12-14, 2017, Istanbul, Turkey. Edited by Sefer Şener

\title{
THE RELATIONSHIP BETWEEN FINANCIAL DEVELOPMENT AND ENTREPRENEURSHIP: PANEL DATA
} ANALYSIS

\author{
DOI: 10.17261/Pressacademia.2017.515 \\ PAP-WCTIE-V.4-2017(7)-p.43-49
}

\section{Duygu Hidiroglu}

duyguhidir@hotmail.com

\begin{abstract}
Entrepreneurship has been one of the most popular topics in recent years due to its continuing dynamism in the Modern Market Economy. Many recent studies investigate the financial obstacles and difficulties in the establishment of new companies and commercial entities.

The purpose of this research is to define entrepreneurship and entrepreneurship concepts in detail, while explaining financial factors and financial mechanisms at the forefront of environmental factors affecting entrepreneurship in the world. Besides, what are the obstacles to entrepreneurship, and how entrepreneurship is influenced by the financial barriers will be explained. The aim is to reduce the number of entrepreneurs who obstruct the economic development. This study assumes that there is a positive relationship between entrepreneurship and four financial factors which are affordability of financial services, ease of access to loans, venture capital availability, and soundness of banks. In this context, four hypotheses related to these factors will be tested by population averaged panel data analysis.
\end{abstract}

Keywords: Entrepreneurship, financing, capital.

JEL Codes: M30

\section{INTRODUCTION}

Entrepreneurship has been one of the most popular topics in recent years, due to its continuing dynamism in the Modern Market Economy and its contribution to economic growth. Three important alterations which are increase in employment, empowered economy and general acceptance of entrepreneurship in the field of academy boost the popularity of entrepreneurship currently. Business investments have a critical impact on productivity of countries. For this reason, economies demand developed and multi-faceted financial markets to provide sources for new investments. Having an effective financial sector; countries should encourage foreign entrepreneurs as well as they support their own local entrepreneurs. Financial markets must be in line with the regulations essential to protect entrepreuners and other actors of the economy. By attracting the market with the highest return rates, countries should allocate resources to support the initiatives and projects of potential investors.

\section{LITERATURE \& HYPOTHESES}

\subsection{Literature Review}

After literature review, it is realized that among many dynamics influencing entrepreneurship, the most effective dynamics of an entrepreneur's movement is financial dynamics. Considering financial impacts on entrepreneurship, academic studies have dealed with some dimensions of financing constraints and barriers.

Financial barriers to entrepreneurship vary according to the development of economies. Most common barriers are property right protection and investment financing. Strong protection of property rights impacts entrepreneurship highly positively (Aids R., Estrin S., Mickiewicz T., 2010). On the contrary, North has argued that the insecurity of property rights could result in little fixed capital and small firms sector (North 1990,p.65). 
High developed economies are more dependent on financing of investments than poor economies because strong institutional environment affects entrepreneurship affirmatively (Aids R., Estrin S., Mickiewicz T., 2010). Glaeser states that where institutions are small and weak, entrepreneurship activities could be restricted and it may cause lack of efficiency (Glaeser et al., 2003;Johnson at al., 1997;Baumol, 1990).

According to Paulson's research, lots of households report that they do not invest due to lack of funds. Business start ups are closely related with wealth of potential entrepreneurs. If entrepreneurial households expand their business, they can undertake profitable opportunity but most of entrepreneurs have no enough money to do so. (Paulson, 2004).

For some ventures, investment is sensitive to cash flows. Financial constraints may mean that entrepreneurs are unable to borrow, or can borrow only a limited amount of money to invest. Less dependence on the availability of outside funding is more advantageous for entrepreneurs (Fazzari, et al.,1988).

In this study, what are the obstacles to entrepreneurship, and how entrepreneurship is influenced by the financial barriers will be explained. The focus is by using new data and approach providing evidence for the relationship between the financial constraints and entrepreneurial activity.

The aim of this study is to reduce the number of entrepreneurs who obstruct the economic development and to prevent the ventures that may have growth problems to increase success of new entrants. To examine how financial factors impact entrepreneurial activities, we asked "How does countries' financial market development affect entrepreneurship?" as a key question of this research.

\subsection{Hypotheses}

The major sources for new investments are strong and trustworthy bank loans, well-regulated securities exchange stocks and venture capital.This study assumes that there is a positive relationship between entrepreneurship and four financial factors which are affordability of financial services, ease of access to loans, venture capital availability, and soundness of banks. In this context, four hypotheses related to these factors will be tested by panel data analysis.

H1: The more affordable the financial service is, the higher entrepreneurship rate is.

Knowing to what extent are financial services affordable for businesses is important for who are new business investors. Especially for poor entrepreneurs do not have enough money for investments; this financial factor can be a vital constraint that prevents new ventures. We can assume that high affordability of financial services could increase the entrepreneurship rate and affect start up projects positively.

H2: The higher the ease of access to loans, the higher the entrepreneurship rate is.

Bank loans are an important source of financing for new businesses and expanding existing ventures. The World Economic Forum's Global Competiveness Report, which collects data through executive opinion surveys, provides insight on individuals' views on access to bank loans in different countries. The World Economic Forum data shows that financing of banks becomes more difficult to obtain between 2007 and 2010 in all countries because of the financial crisis.

Paravisini (2008) shows in the context of Argentina that banks not only face frictions in their access to external financing, but that these frictions prevent them from undertaking profitable investment opportunities in the real economy. Banerjee and Duflo (2008) have similar findings in the context of a directed lending program in India.

Our variable: ease of access to loans describes how easy is it to obtain a bank loan with only a good business plan and no collateral. Besides access to loans; reaching strong and trustworthy loans is important. In order to do so, the finance sector requires being reliable, transparent, and clear.

H3: The more available the venture capital, the higher the entrepreneurship rate is.

Venture capital states the level of investment performed by venture capital firms towards young businesses in seed and start-up phases. Venture capital availability illustrates how easy it is for start-up entrepreneurs with innovative but risky projects to get equity funding.

Venture capital differs significantly among countries and is very sensitive to market cycles in terms both of amounts invested and stages of investment. Regarding current financial environment, venture capital funds may invest in later stages, leaving gaps at stages where profit expectations are less clear and risk is extremely higher.

\section{H4: The higher the soundness of banks, the higher the entrepreneurship rate is.}

Banks were more efficiently run in low and middle-income countries than in high-income countries.(Navajas M. C. and Thegeya A., 2013) Soundness of banks helps the development of the quality of assets and soundness helps to establish typical standards for banks of different size classes, location, deposit composition, etc. (Riefier W., Friday D.,1937) 
In this study, the soundness of banks describes how do you assess the soundness of banks.

This paper continues as follows. Section 3 represents the data \& methodology and the logic behind why the variables are chosen for this study. 4 hypotheses will be tested in this part. Section 4 will discuss the results of the study and Section 5 brings in helpful insights and conclusions to the literature and briefly mentions the limitations of the study.

\section{DATA AND CONSTRUCTION OF VARIABLES}

\subsection{Data}

The sample of data that we use in our analyses is constructed by merging data from four sources, including the World Bank, Global Competitiveness Report database. We did not restrict construction of our sample to a group of countries. However, due to missing data on several variables, our analyses are based on a sample that covers data on 87 countries for the years between 2004 and 2014. Our sample consists of 87 countries. Therefore, we feel that our final sample fairly represent the entire population of interest.

In our study, we explore a balanced panel data of 10 years. We prefer panel data, since by blending the variation over time and variation over dynamics we can realize estimates of unobservable country effects. This analysis has several advantages over cross-sectional or time-series data. (Hsiao)

\section{Table1: Summary Statistics}

\begin{tabular}{|c|c|c|c|c|c|c|c|}
\hline \multicolumn{2}{|c|}{ Variables } & Obs & Mean & d. Dev. & Min & Max & Data Source \\
\hline 2 & Affordability & 326 & 4,31 & 0,85 & 2,01 & 6,02 & Global Competitiveness Index \\
\hline 4 & Venture capital & 661 & 3,04 & 0,85 & 1,44 & 5,39 & Global Competitiveness Index \\
\hline 5 & SBNK & 661 & 5,34 & 0,90 & 1,44 & 6,90 & Global Competitiveness Index \\
\hline 6 & GDP (log) & 655 & 25,14 & 1,82 & 20,44 & 29,36 & World Bank \\
\hline 8 & Labor market efficiency & 653 & 4,40 & 0,53 & 2,79 & 5,95 & Global Competitiveness Index \\
\hline 9 & Num. procedures to start bus. & 644 & 7,47 & 3,44 & 1,00 & 18,00 & Global Competitiveness Index \\
\hline 10 & Inflation & 647 & 4,94 & 4,50 & $-4,86$ & 44,39 & World Bank \\
\hline 11 & Quality of higher education & 653 & 4,31 & 0,92 & 1,90 & 6,22 & Global Competitiveness Index \\
\hline
\end{tabular}

Table 1 presents the summary statistics of our sample. We first utilize multilevel linear modeling and maximum likelihood estimation technique to analyze the relationship between financial dimensions and new business density. The analysis accounts for the standard deviations which are associated with the overall error term. (Rabe-Hesketh and Skrondal, 2012; STATA Documentations, 2015).

\subsection{Entrepreneurship Rate}

The dependent variable of this study is entrepreneurship rate. The World Bank data represents the entrepreneurship rates of countries for 2016. These rates differ from one country to another. This variable indicates how many entrepreneurs from every hundred people are in one country. The entrepreneurship ratio is calculated by dividing the number of new entrants entering the market during the year by the total number of firms.

\subsection{Independent Variables}

To test the hypotheses, the Global Competitiveness Report 2016 (WEF, 2015-2016) data is used.

The affordability of financial services: This variable measures that in one country, to what extent are financial services affordable for businesses? [1 = not affordable at all; 7 = affordable] | 2013-14 weighted average (WEF, 2015-2016).

Ease of access to loans: This variable measures that in one country, how easy is it to obtain a bank loan with only a good business plan and no collateral? [1 = extremely difficult; 7 = extremely easy] | 2013-14 weighted average (WEF, 20152016).

Venture capital availability: This variable measures that in one country, how easy is it for start-up entrepreneurs with innovative but risky projects to obtain equity funding? [1 = extremely difficult; 7 = extremely easy] | 2014-15 weighted average (WEF, 2015-2016).

Soundness of banks: This variable measures that in one country, how do you assess the soundness of banks? [ $1=$ extremely low-banks may require recapitalization; 7 = extremely high-banks are generally healthy with sound balance sheets] । 2014-15 weighted average (WEF, 2015-2016). 


\subsection{Control Variables}

GDP (log): This variable states the gross domestic product valued at purchasing power parity in billions of international dollars.

Total Tax Rate: The total tax rate measures the amount of taxes and mandatory contributions payable by a business in the second year of operation, expressed as a share of commercial profits. The total amount of taxes is the sum of five different types of taxes and contributions payable after accounting for deductions and exemptions: profit or corporate income tax, social contributions and labor taxes paid by the employer, property taxes, turnover taxes, and other small taxes.

Labor Market Efficiency: Regarding this variable; efficiency is measured by 8 dimensions which are cooperation in laboremployer relations, flexibility of wage determination, hiring and firing practices, redundancy costs, effect of taxation on incentives to work, pay and productivity, reliance on professional management, country capacity to retain talent, country capacity to attract talent, female participation in the labor force.

Num. Procedures to Start Business: This variable indicates the number of procedures required to start a business.

Inflation: This variable shows the annual percent change in consumer price index (year average).

Quality of higher education: This variable responds the question of how do you assess the quality of primary schools in your country? [ 1 = extremely poor-among the worst in the world; 7 = excellent-among the best in the world] | 2014 Source: International Monetary Fund, World Economic Outlook Database (April 2015 edition)

Table 2: Correlations

\begin{tabular}{|c|c|c|c|c|c|c|c|c|c|c|c|c|}
\hline \multicolumn{2}{|c|}{ Variables } & 1 & 2 & 3 & 4 & 5 & 6 & 7 & 8 & 9 & 10 & 11 \\
\hline$\overline{1}$ & New business density (log) & 1,00 & & & & & & & & & & \\
\hline 2 & Affordability & 0,43 & 1,00 & & & & & & & & & \\
\hline 3 & Loan & 0,48 & 0,78 & 1,00 & & & & & & & & \\
\hline 4 & Venture capital & 0,48 & 0,79 & 0,94 & 1,00 & & & & & & & \\
\hline 5 & SBNK & 0,34 & 0,60 & 0,68 & 0,61 & 1,00 & & & & & & \\
\hline 6 & GDP (log) & 0,18 & 0,52 & 0,34 & 0,42 & 0,27 & 1,00 & & & & & \\
\hline 7 & Total tax rate & $-0,27$ & $-0,09$ & $-0,18$ & $-0,13$ & $-0,13$ & 0,26 & 1,00 & & & & \\
\hline 8 & Labor market efficiency & 0,47 & 0,51 & 0,54 & 0,55 & 0,30 & 0,14 & $-0,39$ & 1,00 & & & \\
\hline 9 & Num. procedures to start bus. & $-0,40$ & $-0,25$ & $-0,24$ & $-0,26$ & $-0,15$ & $-0,09$ & 0,32 & $-0,44$ & 1,00 & & \\
\hline 10 & Inflation & $-0,30$ & $-0,40$ & $-0,21$ & $-0,25$ & $-0,17$ & $-0,33$ & 0,07 & $-0,20$ & 0,28 & 1,00 & \\
\hline 11 & Quality of higher education & 0,59 & 0,67 & 0,58 & 0,65 & 0,33 & 0,61 & 0,05 & 0,52 & $-0,40$ & $-0,42$ & 1,00 \\
\hline
\end{tabular}

Table 2 illustrates the correlations for all variables. Regarding this table, we do not expect to see there is a relationship between our dependent variable (entrepreneurship rate) and our independent variables (affordability of financial services, ease of access to loans, venture capital availability and soundness of banks).

According to Table 2, we realize that the correlation between these variables and the entrepreneurship rate is high and significant and it obligates us to observe this relationship in a multivariate setting. Besides, all explanatory variables are significantly correlated with new business density. The correlation between the variables; total tax rate, num. procedures to start bus., inflation, and the dependent variable seems to be significantly negative, which suggest that their impact on new business density is not much in recent years.

\subsection{Model}

This study explores ten-year data of 87 countries. In our study, population averaged panel data is used. The population averaged model does not fully specify the distribution of the population, it specifies only a marginal distribution (Nauhaus J. M., 1992).The regression model is stated as follows:

$$
\text { yit }=+\alpha+x i t \beta+u i+€ i t
$$

In this mentioned model, $\mathbf{i}$ represents country and $\mathbf{t}$ represents year. $\mathbf{y}$ represents the new business density; $\alpha$ is a constant; $\mathbf{X}_{,}$, is a vector of country level variables that includes four dimensions of the financial environment (affordability of financial services, ease of access to loans, venture capital availability and soundness of banks) and control variables (log of GDP, total tax rate, labor market efficiency, num. procedures to start bus., inflation, and quality of higher education). u represents the country specific effect. $€$ is the overall error term and is assumed to have i.i.d. normal distribution. Our estimators eliminate the country specific effect by taking the first difference of all variables in the model.

\section{FINDINGS AND DISCUSSIONS}

\subsection{Regression Estimates}


Table 3 presents the regression analyses of our 4 hypotheses. Model 1,2,3 and 4 present the estimate of our variables respectively; affordability of financial services, ease of access to loans, venture capital availability and soundness of banks. Model 1 seems to be highly significant because wald chi. sq. $=102,8, p<0.00$. Model 2 has the value of wald chi sq. $=83,45$, $p<0$, Model 3 has the value of wald chi $s q .=87,18, p<0$, and Model 4 has the value of wald chi $s q .=75,35, p<0$ as well; so that all the models in that study as a whole appears to be highly significant.

According to Hypothesis 1 , the entrepreneurship rate increases as the value of affordability of financial services increases. As our expectation, there is a positive but insignificant relationship between the value of entrepreneurship rate and affordability $(\beta=0,024, p>0,803) \beta$ value is positive but probability is higher than 0,05 which states insignificance. This result suggests that affordability has no significant effect on entrepreneurship rate as we consider.

Especially for low income entrepreneurs, increasing the supply of affordable financial services and credit is required to be strengthened because by doing this, business development initiatives can be expanded and entrepreneurs can be encouraged (Birkenmaier J., Watson S.,2005).

\section{Table 3: Regression Estimates}

\begin{tabular}{|c|c|c|c|c|c|c|c|c|c|c|}
\hline \multirow[b]{2}{*}{ Variable } & \multicolumn{2}{|c|}{ Control model } & \multicolumn{2}{|c|}{ Model 1} & \multicolumn{2}{|c|}{ Model 2} & \multicolumn{2}{|c|}{ Model 3} & \multicolumn{2}{|c|}{ Model 4} \\
\hline & Coff. & $\overline{P>}|\mathrm{z}|$ & Coff. & $\mathrm{P}>|\mathrm{z}|$ & Coff. & $\mathrm{P}>|\mathrm{z}|$ & Coff. & $\overline{P>|z|}$ & Coff. & $\bar{P}>|z|$ \\
\hline Affordability & & & 0,024 & 0,803 & & & & & & \\
\hline Loan & & & & & 0,125 & 0,001 & & & & \\
\hline Venture capital & & & & & & & 0,159 & 0,000 & & \\
\hline SBNK & & & & & & & & & 0,064 & 0,054 \\
\hline GDP $(\log )$ & $-0,009$ & 0,867 & $-0,100$ & 0,069 & $-0,025$ & 0,647 & $-0,026$ & 0,629 & $-0,021$ & 0,702 \\
\hline Total tax rate & $-0,007$ & 0,068 & $-0,015$ & 0,001 & $-0,007$ & 0,044 & $-0,008$ & 0,032 & $-0,007$ & 0,064 \\
\hline Labor market efficiency & 0,203 & 0,050 & 0,150 & 0,267 & 0,120 & 0,251 & 0,137 & 0,185 & 0,182 & 0,078 \\
\hline Num. procedures to start bus. & 0,007 & 0,601 & $-0,007$ & 0,739 & 0,000 & 0,989 & $-0,003$ & 0,827 & 0,003 & 0,788 \\
\hline Inflation & 0,000 & 0,959 & $-0,008$ & 0,531 & $-0,004$ & 0,520 & $-0,003$ & 0,579 & $-0,002$ & 0,751 \\
\hline Quality of higher education & 0,527 & 0,000 & 0,746 & 0,000 & 0,508 & 0,000 & 0,491 & 0,000 & 0,532 & 0,000 \\
\hline Constant & $-2,193$ & 0,098 & $-0,187$ & 0,885 & $-1,657$ & 0,204 & $-1,668$ & 0,198 & $-2,128$ & 0,103 \\
\hline Observations & 625 & & 310 & & & & & & 625 & \\
\hline Number of groups & 102 & & 98 & & & & & & 102 & \\
\hline Wald chi sq. & 69 & & 102,88 & & 83,45 & & 87,18 & & 75,35 & \\
\hline Prob > chi sq & 0 & & 0 & & 0 & & 0 & & 0 & \\
\hline
\end{tabular}

Hypothesis 2 states that the entrepreneurship rate increases as the value of ease of access to loans increases. There is a positive and significant relationship between the entrepreneurship rate and loan $(\beta=0,125, p<0,001)$. This result emphasizes that high ease of access to loans has positive impact on the entrepreneurship rates. In competitive markets, firms have enough access to alternative sources of credit for their new investments. Cetorelli argues that high ease of access to loans may foster a more competitive and especially bank- dependent industrial sectors; thereby reducing credit availability to potential start ups who menace to compete with attendends and offer the loans to those incumbents less worthy (Cetorelli, 2001).

Hypothesis 3 proposes that the entrepreneurship rate increases as the venture capital is more available. Since $\beta$ value is positive and equals to 0,125 and probability is equal to 0,00 , the result indicates that there is a positive and significant relationship between the entrepreneurship rate and venture capital.

Start up firms have formed their own venture capital divisions to provide risk capital for expansion and early-stage financing. Venture capital provides companies a portion of their or other owners' interest in the company in exchange for the VCs' backing instead of paying out hard-to-get cash in the form of interest and principal installments.

Hypothesis 4 states that the entrepreneurship rate increases as the value of soundness of banks increases. In our results, $\beta$ value is 0,064 and $p>0,054$ which means there is a positive but insignificant relationship between the entrepreneurship rate and the soundness of banks.

Banks have respectable effect on especially small and young firms' enterance to markets. In general, there is close link between bank stability and new business creation. Since, strong banks preserve new businesses from negative effects of market competition by overcoming obstacles. Moreover, nonbank financial institutions have become increasingly crucial providers of loans to entrepreneurs; so that, the soundness of banks and robust bank structure become more significant in order to not negatively affected by this new condition (Black S. \& Strahan P., 2002).

\section{CONCLUSION}

Entrepreneurs accelerate the creation, dissemination and implementation of new ideas. An entrepreneur provides benefits to economy in many ways. Entrepreneurs combine production resources by a new manner to make use of unused 
production factors to improve productivity while operating existing inputs of the production tools already being used with different methods to increase production. Whether the successes or failures of entrepreneurs are examples for other entrepreneurs and guide them for their attempt to new businesses.

In this paper, after scanning the literature we realize that there are many studies about financial constraints of entrepreneurship, but the methodology and the controlling sample selection we chose for our study is different from the approach of other studies examined. In our study, we try to analyze the relationship between entrepreneurship and financial constraints. The reason why we preferred a disparate approach is to provide unexplored insights for academic background.

After explicating the results of our testing, substantial evidence could be easily attained that financial dimensions have vital importance on start up businesses in countries. Financial barriers and constraints crucially impact the entrepreneurship rates, since returns to business investment tend to increase with wealth and financial development as well as with entrepreneurial talent.

After testing our 4 hypotheses we realized that there is a weak link between our two financial dimensions: affordability of financial services, soundness of banks and the enrepreneurship rate. On the other hand, our analyses provide evidence on the relationship between two other financial dimensions; ease of access to loans and the venture capital availability and the entrepreneurship rate.

In this study, the relationship between the financial environment and entrepreneurship rates is explored. To analyze this relationship, a longer panel than one that is used in this study may be better. So that, the shortness of the panel used in this study may be regarded as a limitation for our study.

We conclude that future researches could include any other financial dimensions which have strong relationship between the entrepreneurship activities and start up businesses. The conclusion of this study is empowered by the used statistical approaches which allow us to make sure findings are robust to alternative functional forms and the inclusion of further control variables (Kerr, Nanda, 2009).

\section{REFERENCES}

Aidis R., Estrin S., Mickiewicz T., Institutions, Finance and the Level of Development: the Impact on Entrepreneurship in Transition, Review of Economics and Institutions, ISSN 2038-1379 DOI 10.5202/rei.v1i1.3, Vol. 1 - No. 1, Spring 2010 - Article 3

Anna L. Paulson, Robert Townsend, Entrepreneurship and financial constraints in Thailand, Journal of Corporate Finance 10 (2004) 229 262

Banerjee, A., E. Duflo, and K. Munshi (2003) 'The (mis)allocation of capital', Journal of the European Economic Association, 1 (2-3), $484-94$.

Birkenmaier J., Watson S.,(2005), Affordable Financial Services and Credit for the Poor: The Foundation of Asset Building, Journal of Community Practice, Vol. 13(1)

Black S. and Strahan P., (2002),Entrepreneurship and Bank Credit Availability, The Journal of Finance * Vol. LVII, No. 6 *

Brander, J. \& Amit, R. (1998).Why Do Venture Capital Firms Exist? Theory and Canadian Evidence.

Brander, J., K. Hendricks, R. Amit, and D. Whistler. (1998). The engine of growth hypothesis: On the relationship between fi rm size and employment growth work. University of British Columbia, Department of Economics. Manuscript.

Cetorelli, Nicola, 2001, Does bank concentration lead to concentration in industrial sectors? Working paper 01-01, Federal Reserve Bank of Chicago

Fazzari, S., Hubbard, R.G., Petersen, B., 1988. Financing constraints and corporate investment. Brookings Papers on Economic Activity 1, $141-195$

Glaeser, E., Scheinkman, J., \& Shleifer, A. (2003). Injustice of Inequality.

Journal of Monetary Economics, 50 (1), 199-222. doi:10.1016/S0304- 3932(02)00204-0

Hsiao C., Panel Data Analysis - Advantages and Challenges, Sociedad de Estad'ıstica e Investigaci'on Operativa Test (0000) Vol. 00, No. 0, pp. 1-63, Department of Economics, University of Southern California, USA Wang Yanan Institute for Studies in Economics, Xiamen University, China

Kerr W., Nanda R., (2009), Financing Constraints and Entrepreneurship, Working Paper 15498

Klapper, L., Laeven, L., and Rajan, R. (2006). Entry regulation as a barrier to entrepreneurship. Journal of Financial Economics (p. 591-629).

Navajas M. C. and Thegeya A., (2013)Financial Soundness Indicators and Banking Crises, IMF Working Paper, International Monetary Fund 
Neuhaus J.M.,(1992), Statistical Methods for Longitudinal and Clustered Designs with Binary Responses, Statistical Methods in Medical Research 1:249-273.

North, D. (1990). Institutions, Institutional Change and Economic Performance. New York: Cambridge University Press

Paravisini, D. (2008), 'Local bank financial constraints and firm access to external finance', Journal of Finance, 63 (5), 2161-93.

Riefier W., Friday D., Lichtenstein W., Riddle J. H., (1937), Soundness of Financial Institutions, (p. 87 - 98)

Small Business Encyclopedia, 2017, Entrepreneur Media, https://www.entrepreneur.com/encyclopedia/venture-capital 